\title{
Innovation in Using the Quizizz-Assisted Zoom Application in Chemistry Learning during the Covid-19 Pandemic
}

\author{
Leony Sanga Lamsari Purba ${ }^{1}$, Sali Afridika ${ }^{2}$, Yohana Junita ${ }^{3}$ \\ ${ }^{1,2}$ Universitas Kristen Indonesia, ${ }^{3}$ SMA Pelita Kasih
}

\begin{abstract}
This study aims to determine the increase in learning outcomes using the quizizz-assisted zoom application in chemistry learning during the Covid-19 pandemic. This research is quantitative research with a population of all students of SMA Pelita Kasih and the sample using the True Experimental method takes the Pretest - Posttest Control Group Design. The analysis test was carried out using paired t-test and n-gain score. The results showed an increase in learning outcomes using the quizizz-assisted zoom application in chemistry learning during the Covid-19 pandemic with $t_{\text {table }}(1.69) t_{\text {count }}(10.12)$ and sig $0.05(\mathrm{df}=31)$. Gain test results were obtained by $54.68 \%$ in the medium category, so it can be concluded that learning with the Quizizz application is effective in improving cognitive abilities and encouraging students to interact and compete towards better competencies.
\end{abstract}

Kata kunci: Covid-19, Online Learning, Quizizz, Zoom

\section{Inovasi Penggunaan Aplikasi Zoom Berbantuan Quizizz pada Pembelajaran Kimia di Masa Pandemik Covid-19}

\begin{abstract}
Abstrak
Penelitian ini bertujuan untuk mengetahui peningkatan hasil belajar dengan menggunakan aplikasi zoom berbantuan quizizz pada pembelajaran kimia pada masa pandemi Covid-19. Penelitian ini merupakan penelitian kuantitatif dengan populasi seluruh siswa SMA Pelita Kasih dan sampel dengan mempergunakan metode True Experimental mengambil Pretest - Posttest Control Group Design. Uji analisis dilakukan dengan menggunakan uji t berpasangan dan $\mathrm{n}$-gain score. Hasil penelitian menunjukkan adanya peningkatan hasil belajar menggunakan aplikasi zoom berbantuan quizizz pada pembelajaran kimia pada masa pandemi Covid-19 dengan $t$-tabel $(1,69)$ $t_{\text {hitung }}(10,12)$ dan sig $0,05(\mathrm{df}=31)$. Hasil uji gain diperoleh sebesar 54,68\% dalam kategori sedang, sehinnga dapat disimpulkan pembelajaran dengan aplikasi quizizz efektif meningkatkan kemampuan kognitif dan mendorong siswa untuk berinteraksi dan bersaing menuju kopetensi yang lebih baik.
\end{abstract}

Kata kunci: minimal dua kata atau frase penting yang mewakili artikel. 


\section{PENDAHULUAN}

Judul Protokol Kementrian kesehatan Indonesia tidak menyarankan pembelajaran secara offline pada masa pandemik Covid-19. Hal ini terkait dengan peningkatan jumlah kasus Covid-19 di Indonesia setiap harinya (PENYUSUN, 2020). Menurut BNPB (2020), per hari kamis (04/06/2020) pemerintah Indonesia telah mengkonfirmasi peningkatan kasus Covid-19, pasien yang awalnya positif sebanyak 585 orang mengalami peningkatan menjadi 28.818 orang. Kemudian pasien yang sembuh menigkat menjadi 8.892 orang setelah adanya penambahan 486 orang, dan pasien yang telah meninggal mengalami peningkatan hingga mencapai 1.721 orang.

Pada masa pandemik ini, seluruh dunia memiliki tujuan yang sama: kasus Covid19 harus mencapai nol (Roser, Ritchie, Ortiz-Ospina \& Hasell., 2020). Berbagai langkah dilakukan oleh pemimpin di setiap negara untuk mencapai tujuan tersebut. Di Indonesia, pemerintah telah memberikan himbauan-himbauan kepada masyarakat dalam mengatasi wabah ini agar berjalan efektif dan efisien, namun pada kenyataannya himbauan ini masih belum di indahkan oleh beberapa kelompok masyarakat Indonesia (Buana, 2020). Masyarakat Indonesia seharusnya mengikuti berbagai hal yang disarankan pemerintah, demi kebaikan bersama (Teaumbanua, 2020). Salah satu bentuk kontribusi masyarakat agar penanganan oleh tim medis dapat terlaksana dengan baik adalah mengikuti himbauan pemerintah yaitu social distancing. Tujuan pemerintah menerapkan social distancing ini adalah agar penularan Covid-19 tidak semakin bertambah, oleh karena itu Presiden Joko Widodo meghimbau masyarakatnya untuk melaksanakan segala kegiatan dirumah saja (Work From Home disingkat WFH) seperti kegiatan ibadah, bekerja dan juga belajar. Meski hanya melaksanakan kegiatan dirumah saja (WFH) masyarakat masih bisa berhubungan sosial dengan yang lainnya melalui media online (Astuti et al., 2020)

Pada 20 maret 2020 WHO (World Health Organization) mengatakan bahwa dengan kemajuan teknologi yang sudah dimiliki, masyarakat akan sangat mudah melakukan komunikasi meski berada dalam ruangan yang tidak sama. Dengan demikian pendidik dan peserta didik juga dapat memanfaatkan teknologi yang sudah maju ini, jadi tidak perlu lagi melaksanakan pembelajaran secara offline, karena pembelajaran offline bisa dialihkan ke pembelajaran online (Pakpahan,2020; Sababalat et al. 2021). Menurut Kompas.com (2020), MENDIKBUD (Menteri Pendidikan dan Kebudayaan) Nadiem Makarim pandemik Covid-19 ini membawa berbagai macam hikmah secara khusus 
didunia pendidikan, karena pandemik Covid-19 ini membuat guru dan orang tua sadar bahwa belajar dapat dilakukan dimana saja. Menurut Darmadi (2017) belajar merupakan rangkaian kegiatan atau aktivitas yang di lakukan dengan sadar oleh seseorang yang mengakibatkan perubahan melalui alat indera dan pengalamannya. Dan juga menurut Nadiem Makarim pembelajaran secara online ini dapat membuat masyarakat Indonesia berinovasi untuk mengembangkan kemajuan teknologi yang sudah semakin maju. Pembelajaran online ini dapat dilaksanakan dengan menggunakan perangkat komputer atau gadget yang bisa menghubungkan antara peserta didik dan pendidik (Kusumadewi et al, 2020). Ada banyak sekali aplikasi seperti moodle (Kurniawan et al. 2020), nearpod (Delacruz, 2014), microsoft office 365 (Purba, 2021) dan masih banyak lagi yang dapat kita pasang dan gunakan untuk pembelajaran online kita agar dapat berjalan dengan lancar.

Salah satu aplikasi lain yang dapat menghubungkan antara pendidik dan peserta didik adalah aplikasi Zoom. Penggunaan aplikasi Zoom sebelum tanggal 19 maret 2020 mencapai 91.030 orang pengguna, hingga pada tanggal 26 maret 2020 meningkat hingga mencapai 257.853 pengguna. Salah satu keuntungan bagi pengguna aplikasi Zoom adalah sistem aplikasi di dalamnya sangat simpel sehingga mudah untuk dimengerti pendidik dalam menggunakannya. Keuntungan lainnya adalah mudah diakses dan dapat membantu pendidik dan peseta didik mengadakan meeting dengan video confernce. Aplikasi Zoom bisa dikatakan aplikasi yang sering digunakan saat video conference, karena kapasitas orang yang dapat bergabung dalam meeting maupun video confernce mencapai 100 orang dan telah tercatat lebih dari 90.000 sekolah di 20 negara yang menggunakan aplikasi ini (Hidayatullah, 2020). Setelah diteliti ternyata mayoritas pengguna aplikasi Zoom mengeluh dengan aplikasi ini, karena penggunaan aplikasi ini sangat menguras kuota, sekalipun hasil uji yang di lansir CBNC Indonesia.com menyatakan bahwa kebutuhan bandwidth Zoom sekitar 700 kbps. Kemudian pembelajaran online dengan aplikasi Zoom ini juga dianggap kurang efektif, karena ketika menggunakan aplikasi ini saat sinyal tidak stabil maka akses akan terputus-putus. (Naserly, 2020).

Aplikasi Zoom yang membutuhkan kuota dengan jumlah yang banyak mengakibatkan peserta didik dan pendidik tidak mungkin menggunkan aplikasi ini dengan waktu yang cukup lama. Tetapi dilain sisi pendidik juga harus tetap melakukan pembelajaran mulai dari pembukaan hingga evaluasi terhadap pembelajaran. Evaluasi 
pembelajaran yang dapat dilakukan oleh pendidik bisa menggunakan media evaluasi pembelajaran Quizizz pada akhir pembelajaran. Menurut Purba (2019), menggunakan Quizizz ini dapat membantu pendidik melakukan evaluasi pembelajaran dengan baik, media ini juga dapat membuat peserta didik tidak terlalu bosan karena media ini memiliki tampilan yang menarik dan memiliki pengaturan waktu hingga dapat membantu peserta didik menjadi lebih konsentrasi ketika mengisi jawaban dari kuis tersebut. Pengunnaan quizizz dapat menimbukan rasa senang belajar bagi siswa, karena quizizz seperti game online yang menarik (Purba, 2018). Selanjutnya, setelah melakukan kuis pendidik tidak perlu lagi mengoreksi jawaban peserta didik satu persatu, karena melalui media ini pendidik dapat melacak jumlah jawaban peserta didik dan pendidik juga dapat mendownload data dan statistik dalam bentuk spreadsheet exel. Dalam pengaplikasiannya, maka zoom dan quizizz harus dirancang pada model pembelajaran yang sesuai juga (Junita \& Purba, 2019). Uraian di atas menajadi dasar pelaksanaan penelitian ini dilaksanakan. Tujuan utama pelaksanaan penelitian ini adalah untuk mengetahui “Apakah Terdapat Peningkatan Hasil Belajar dengan Menggunakan Aplikasi Zoom Berbantukan Quizizz Pada Pembelajaran Kimia di Masa Pandemik Covid-19”.

\section{METODE PENELITIAN}

Pada Untuk mengetahui efektivitas aplikasi Zoom berbantukan quizizz dalam pembelajaran pada masa pandemik Covid-19 dalam meningkatkan hasil belajar siswa, peneliti menerapkan metode eksperimen. Populasi yang digunakan dalam penelitian ini adalah seluruh siswa SMA Pelita Kasih. Sampel penelitian adalah siswa kelas XI dengan jumlah siswa sebanyak 32 orang, dengan teknik purposive sampling. Terhadap sampling yang digunakan diberikan pretest lalu pembelajaran dengan menggunakan aplikasi Zoom berbantukan quizizz, kemudian posttest. Berdasarkan penjelasan tersebut, design penelitian ini adalah one grup pretest posttest design, seperti pada gambar berikut ini Creswell, (2002):

\begin{tabular}{lll}
\hline $\mathbf{T}_{1}$ & $\mathbf{Q}$ & $\mathbf{T}_{2}$ \\
\hline
\end{tabular}

Gambar 1. Design Penelitian one grup pretest posttest design

Keterangan:

$\mathrm{T}_{1}=$ Pretest

$\mathrm{Q}=$ Pembelajaran dengan aplikasi Zoom berbantukan Quizizz 
$\mathrm{T}_{2}=$ Posttest

Teknik pengambilan data dalam penelitian ini adalah metode yang terdiri dari pretest dan posttest. Bentuk instrumen test yang digunakan adalah pilihan berganda sebanyak 35 soal dengan option A, B, C, D dan E. Instrumen test yang akan digunakan divalidasi dengan teknik expert judgemen atau pendapat dari ahli yaitu dosen pendidikan kimia FKIP UKI. Instrumen yang sudah peneliti buat dikonsultasikan pada expert judgemen, kemudian akan diberikan keputusan apakah instrumen tersebut valid atau tidak valid dengan beberapa perbaikan, kemudian digunakan dalam penelitian.

Data yang diperoleh terlebih dahulu diuji persyaratan analisis yaitu uji normalitas. Uji ini digunakan untuk mengetahui apakah data yang dianalisis berasal dari populasi yang terdistribusi normal atau tidak. Pengujian normalitas menggunakan SPSS versi 24 dengan berdasarkan pada uji Shapiro-wilk. Untuk menetapkan kenormalan data, taraf signifikan uji menggunakan $\alpha=0.05$. Jika signifikansi yang diperoleh $>\alpha$, maka sampel berasal dari populasi yang berdistribusi normal. Uji selanjutnya adalah uji analisis data. Pada penelitian ini, uji analisis data yang digunakan adalah uji hipotesis $T$ test dengan nilai Sig. $(2$-tailed $)<0.05$ maka hipotesis terbukti artinya $\mathrm{H}_{0}$ ditolak dan $\mathrm{H}_{\mathrm{a}}$ diterima, dengan hipotesis statistik sebagai berikut:

Jika $+t_{\text {tabel }}<\mathrm{t}_{\text {hitung }}$ maka Ho diterima dan Ha ditolak

$\mathrm{Jika}+\mathrm{t}_{\text {tabel }}>\mathrm{t}_{\text {hitung }}$ maka Ho ditolak dan Ha diterima.

Ha: Terdapat peningkatan hasil belajar dengan Menggunakan Aplikasi Zoom Berbantukan Quizizz Pada Pembelajaran di Masa Pandemik Covid-19

Ho: Tidak terdapat peningkatan hasil belajar dengan Menggunakan Aplikasi Zoom Berbantukan Quizizz Pada Pembelajaran di Masa Pandemik Covid-19

Untuk mengetahui berapa besar peningkatan hasil belajar kimia siswa, maka dilakukan uji lanjutan, yaitu uji gain (g) dengan rumus sebagai berikut:

$$
\% \mathrm{~g}=\frac{\text { skror pretest-Skor posttest }}{\text { skor ideal-skor pretest }} \times 100 \%
$$

Hasil uji gain dengan menggunakan rumus diatas dapat diinterpretasikan seperti yang disajikan dalam tabel 1 berikut ini:

\section{Tabel 1. Interpretasi Gain}

\begin{tabular}{cc}
\hline $\boldsymbol{\%} \mathbf{g}$ & Interpertasi \\
\hline $71-100$ & Tinggi \\
$31-70$ & Sedang \\
$0-30$ & Rendah \\
\hline
\end{tabular}


Hake dalam Purba, Sormin, Harefa, Sumiyati (2019)

\section{HASIL DAN PEMBAHASAN}

Hasil Penelitian ini dilakukan di SMA Pelita Kasih kelas XI dengan jumlah siswa 32 orang siswa. Intrumen yang sama digunakan dalam penelitian ini adalah prettest dan posttest. Intrumen yang dibagikan pada kelas sampel sebelum dan sesudah dengan perlakuan (treatment). Prettest dilaksanakan untuk mengetahui kemampuan awal siswa sedangkan posttest dilakukan setelah diberikan perlakuan (treatment). Data hasil pretest dan posttest yang digunakan berbentuk pilihan ganda sebanyak 35 butir soal. Pemberian pretes pada kelompok eksperimen dan kelompok kontrol dilakukan untuk mengetahui kondisi awal peserta didik sebelum dilakukan perlakuan. Deskripsi data hasil pretes dan posttest terlihat pada tabel 2 berikut:

\section{Tabel 2. Deskripsi Data Pretes dan Posttest}

\begin{tabular}{|c|c|c|c|c|c|}
\hline \multicolumn{6}{|c|}{ Descriptive Statistics } \\
\hline Test & $\mathrm{N}$ & Minimum & Maximum & Mean & $\begin{array}{c}\text { Std. } \\
\text { Deviation }\end{array}$ \\
\hline Pretest & 32 & 66.00 & 82.00 & 74.00 & 5.30 \\
\hline Posttest & 32 & 77.00 & 95.00 & 88.22 & 4.47 \\
\hline
\end{tabular}

Rata-rata nilai pretes adalah 74.00 dengan standar devisi 5.30. Rata-rata nilai postest sebesar 88.22 dengan standar devisi 4.47 Dari tabel dapat terlihat rata-rata nilai pretes dan postest memiliki perbedaan tetapi tidak jauh beda hasil yang diperoleh., yaitu selisih 11.00 untuk nilai minumum, selisih 13.00 untuk nilai maksimum dan selisih 14.22 untuk nilai rata-rata pretest dan posttest. Lebih rinci, sebaran nilai pada pretest dan posttes disajikan dalam histogram pada gambar 2 dan 3 dibawah ini:

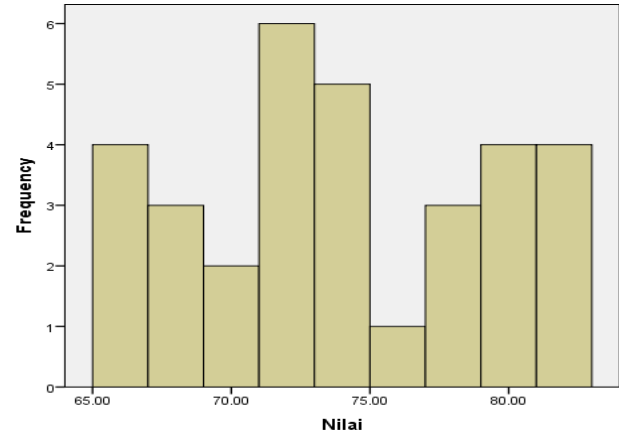

Gambar 2. Rata-rata nilai pretes $\mathrm{P}$

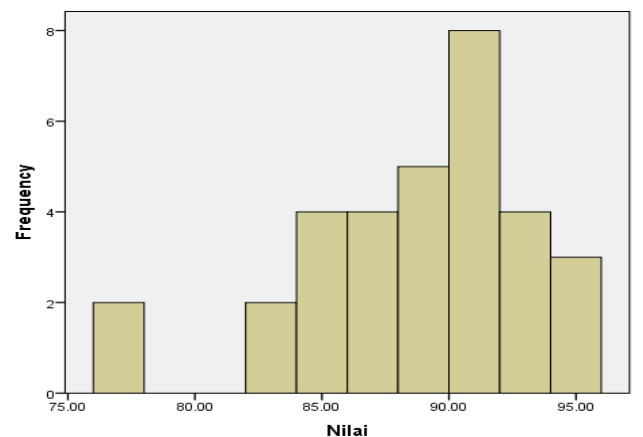

Gambar 2. Rata-rata nilai posttest 
Berdasarkan gambar 2 dan 3 diatas, nilai pretest dominan diantara 70.00 hingga 75.00 sedangkan nilai posttest dominan diantara 90.00 hingga 95.00. Data pretest yang diperoleh di uji normalitasnya dengan menggunakan SPPS 24, Shapiro-wilk. Hasil uji normalitas data disajikan dalam tabel 3 berikut ini:

Tabel 3. Hasil Uji Normalitas

\begin{tabular}{ccccc} 
& \multirow{4}{*}{ Test } & \multicolumn{3}{c}{ Shapiro-Wilk } \\
\cline { 2 - 5 } Nilai & Statistic & Df & Sig \\
\cline { 2 - 5 } & 1.00 & .926 & 31 & .30 \\
2.00 & .930 & 31 & .38 \\
\hline
\end{tabular}

Berdasarkan tabel diatas, hasil uji normalitas pretes diperoleh sebesar Sig.> 0,05. Dengan demikian dapat disimpulkan bahwa kedua kelompok berdistribusi normal.

Data pretest dan posttes dianalisis dengan menggunakan SPPS 24 untuk menjawab rumusan masalah yang dalam penelitian. Hasil analisis, yaitu uji hipotesis t-paired test disajikan dalam tabel 4 berikut ini:

Tabel 4. Hasil Uji Hipotesis

\begin{tabular}{|c|c|c|c|c|c|c|c|c|}
\hline & \multicolumn{5}{|c|}{ Paired Differences } & \multirow{3}{*}{$\mathrm{t}$} & \multirow{3}{*}{$\mathrm{df}$} & Sig. \\
\hline & \multirow[t]{2}{*}{ Mean } & \multirow{2}{*}{$\begin{array}{c}\text { Std. } \\
\text { Deviation }\end{array}$} & \multirow{2}{*}{$\begin{array}{l}\text { Std. Error } \\
\text { Mean }\end{array}$} & \multicolumn{2}{|c|}{$\begin{array}{c}\text { 95\% Confidence Interval of } \\
\text { the Difference }\end{array}$} & & & $\begin{array}{l}(2- \\
\text { tailed }\end{array}$ \\
\hline & & & & Lower & Upper & & & ) \\
\hline Posttest - Pretest & 14.22 & 7.94 & 1.40 & 11.35 & 17.08 & 10.12 & 31 & .000 \\
\hline
\end{tabular}

Berdasarkan tabel 4 di atas, diperoleh nilai Sig.(1-tailed) $0.000<$ probabilitas 0.05. Artinya terdapat peningkatan signifikan dengan dengan demikian Ho ditolak dan Ha diterima. Dengan demikian, terdapat peningkatan hasil belajar kognitif dengan menggunakan aplikasi zoom berbentukan quizizz pada pembelajaran kimia di masa pandemik Covid-19. Dengan menggunakan rumus uji gain dan tafsiran nilai gain pada metodologi penelitian, diperoleh hasil di uji gain sebesar sebesar 54.28\%, pesentase nilai gain ini kategori sedang. Peningkatan hasil belajar yang diharapkan adalah kategori tinggi, dengan persentase nilai gain $\geq 70 \%$. Hasil yang diperoleh hanya pada kategori sedang karena berbagai faktor, salah satunya adalah penggunaan berbagai aplikasi belajar online yang baru digunakan secara rutin. Hal tersebut mengakibatkan penggunaan waktu yang kurang efektif dalam pembelajaran karena guru dan siswa harus beradaptasi dengan pola pembelajaran yang baru. Hasil penelitian ini sejalan dengan Hidayati dan Aslam 
(2021) yang menyatakan bahwa pembelajaran aplikasi Quizizz secara daring cukup efektif dipergunakan untuk perkembangan kognitif siswa. Hasil penelitian Salsabila (2020) yang menyatakan media aplikasi Quizizz sangat efektif digunakan dalam proses pembelajaran.

Penggunaan aplikasi Quizizz dalam penelitian ini mampu meningkatkan peranserta aktif siswa dalam proses pembelajaran sehinnga akan berakibat pada hasil belajar yang lebih baik. Hal tersebut sesuai dengan Citra \& Rosy (2020); Mitasari (2018); Mulyati \& Evendi (2020) yang menyatakan bahwa terjadi peningkatan respon aktif antar siswa dalam bersaing sehingga memicu hasil prestasi belajar yang lebih baik setelah diterapkan pembelajaran menggunakan media pembelajaran aplikasi Quizizz.

\section{SIMPULAN}

Berdasarkan hasil dan pembahasan yang diperoleh, disimpulkan bahwa terdapat peningkatan hasil belajar dengan menggunakan aplikasi zoom berbantukan quizizz dan penggunaan aplikasi Quizizz dalam penelitian ini mampu meningkatkan peranserta aktif siswa berkompetisi dalam proses pembelajaran sehinnga akan berakibat pada hasil belajar yang lebih baik pada pembelajaran kimia di masa pandemik Covid-19. Saran untuk penelitian selanjutnya, untuk mengetahui perubahan peningkatan hasil belajar dengan Aplikasi Zoom berbantukan Quizizz, harus dipaatikan bahwah guru dan siswa sudah beradaptasi dan terbiasa menggunakan Zoom berbantukan Quizizz..

\section{DAFTAR PUSTAKA}

Astuti, D. R., Ma'arif, A. A., Fuad, A., \& Paryati, P. (2020). Analisa pengelolaan kampanye public relations tentang pencegahan Covid-19 di Indonesia

BNPB, (2020). Kasus COVID-19 Bertambah 585, Pasien Sembuh 486 dan Meninggal 23. https://bnpb.go.id/berita/kasus-covid19-bertambah-585-pasien-sembuh-486dan-meninggal-23. diakses pada Rabu (10/06/20) pukul 14:35 WIB.

Buana, D. R. (2020). Analisis Perilaku Masyarakat Indonesia dalam Menghadapi Pandemi Virus Corona (Covid-19) dan Kiat Menjaga Kesejahteraan Jiwa. Salam: Jurnal Sosial dan Budaya Syar-i, 7(3), 217-226.

Citra, C. A., \& Rosy, B. (2020). Keefektifan Penggunaan Media Pembelajaran Berbasis Game Edukasi Quizizz Terhadap Hasil Belajar Teknologi Perkantoran Siswa Kelas $X$ SMK Ketintang Surabaya Jurnal Pendidikan Administrasi Perkantoran (JPAP),8,261-272.

https://journal.unesa.ac.id/index.php/jpap/article/view/8242/4081.

Darmadi, H. (2017). Pengembangn Model dan Metode Pembelajaran Dalam Dinamika 
Belajar Siswa. Yogyakarta: Deepublish.

Delacruz, S. (2014). Using Nearpod in elementary guided reading groups. TechTrends, 58(5), 62-69.

Hidayatullah, S., Khouroh, U., Windhyastiti, I., Patalo, R. G., \& Waris, A. (2020). Implementasi Model Kesuksesan Sistem Informasi DeLone And McLean Terhadap Sistem Pembelajaran Berbasis Aplikasi Zoom Di Saat Pandemi Covid- 19. Jurnal Teknologi dan Manajemen Informatika, 6(1), 45-53.

Junita, Y., \& Purba, L. S. L. (2019). Peningkatan Hasil Belajar Kimia Siswa Melalui Model Pembelajaran Kooperatif Tipe Think Pair Share (TPS) di SMAN 92 Jakarta. Jurnal Dinamika Pendidikan, 12(1), 41-54.

KOMPAS, (2020). Mendikbud : Krisis COVID-19 menyadarkan bahwa belajar dimana saja.

https://nasional.kompas.com/read/2020/05/02/17265601/mendikbud-krisiscovid-19-menyadarkan-bahwa-belajar-bisa-di-mana-saja. diakses pada Kamis (11/06/20) pukul 00:58 WIB.

Kurniawan, A. F., Purba, L. S. L., \& Simanjuntak, F. N. (2021, June). Utilization of Moodle in Increasing Motivation of Learning Chemistry Students. In 2nd Annual Conference on blended learning, educational technology and Innovation (ACBLETI 2020) (pp. 182-188). Atlantis Press.

Kusumadewi, R. F., NEOLAKA, A., \& Yasin, M. (2020). Bahan Ajar Komik Matematika Berbasis Digital Bagi Siswa Sekolah Dasar. Phenomenon: Jurnal Pendidikan MIPA, 10(1), 85-101.

Liu, A. N. A. M. M., \& Ilyas, I. (2020). Pengaruh Pembelajaran Online Berbasis Zoom Cloud Meeting Terhadap Hasil Belajar Mahasiswa Fisika Universitas Flores. Jurnal Pendidikan Fisika dan Keilmuan (JPFK), 6(1), 34-38.

Mitasari, N. R. (2018). Model Pembelajaran Edutaniment Terhadap Perkembangan Kognitif Siswa Sekolah Dasar. Jurnal Cakrawala Pendas, 4(1). https://doi.org/10.31949/jcp.v4i1.698.

Mulyati, S., \& Evendi, H. (2020). Pembelajaran Matematika Melalui Media Game Quizizz Untuk Meningkatkan Hasil Belajar Matematika Smp 2 Bojonegara. Gauss : Jurnal Pendidikan Matematika, 03(01), 64-73. https://doi.org/10.30656/gauss.v3i1.2127.

Naserly, M. K. (2020). Implementasi Zoom, Google Classroom, Dan Whatsapp Group Dalam Mendukung Pembelajaran Daring (Online) Pada Mata Kuliah Bahasa Inggris Lanjut (Studi Kasus Pada 2 Kelas Semester 2, Jurusan Administrasi Bisnis, Fakultas Ekonomi dan Bisnis, Universitas Bina Sa. Aksara Public, 4(2), 155-165.

Pakpahan, R., \& Fitriani, Y. (2020). Analisa Pemanfaatan Teknologi Informasi dalam Pembelajaran Jarak Jauh di Tengah Pandemi Virus Corona Covid-19. Journal of Information System, Applied, Management, Accounting and Research, 4(2), 3036.

Purba, L. S. L. (2021). Microsoft teams 365 and online learning: The student's perception. Jurnal Pendidikan Kimia, 13(2), 130-136. 
Purba, L. S. L. (2018, September). Analisis Minat Belajar Kimia Pokok Bahasan Sistem Periodik Unsur (SPU) Melalui Pemanfaatan Aplikasi Games Atomas pada Android. Seminar Nasional Sains dan Pendidikan Sains XI Tahun 2018.

Purba, L. S. L. (2019). Peningkatan konsentrasi belajar mahasiswa melalui pemanfaatan evaluasi pembelajaran quizizz pada mata kuliah kimia fisika I. Jurnal Dinamika Pendidikan, 12(1), 29-39.

Purba, L. S. L. (2020, June). The effectiveness of the quizizz interactive quiz media as an online learning evaluation of physics chemistry 1 to improve student learning outcomes. In Journal of Physics: Conference Series (Vol. 1567, No. 2, p. 022039). IOP Publishing.

Purba, L. S. L., Sormin, E., Harefa, N., \& Sumiyati, S. (2019). Effectiveness of use of online games kahoot! chemical to improve student learning motivation. Jurnal Pendidikan Kimia, 11(2), 57-66.

Roser, M., Ritchie, H., Ortiz-Ospina, E., \& Hasell, J. (2020). Coronavirus pandemic (COVID-19). Our World in Data

Sababalat, D. F., Purba, L. S. L., \& Sormin, S. (2021). Efektivitas Pemanfaatan Media Pembelajaran Teka-Teki Silang Online Terhadap Peningkatan Minat Belajar Siswa. Edumatsains: Jurnal Pendidikan, Matematika Dan Sains, 6(1), 207-218.

Telaumbanua, D. (2020). Urgensi Pembentukan Aturan Terkait Pencegahan Covid19 di Indonesia. QALAMUNA: Jurnal Pendidikan, Sosial, Dan Agama, 12(1), 59-70. 